\title{
Assessment and Clinical Outcomes of Fall Related Injuries at Emergency
}

Shawbo Muhammad Osman; Department of Nursing, College of Nursing, Hawler Medical University, Erbil, Iraq. (Correspondence: shawbo.othman@hmu.edu.krd)

Vian Afan Naqshbandi; Department of Nursing, College of Nursing, Hawler Medical University, Erbil, Iraq.

\section{ABSTRACT}

Background and objectives: Falls are significant cause of mortality and morbidity with a considerable burden on societies, families and victims. The study aims to determine the interventions and outcomes of fall-related injuries, and the association between injury severity and fall height.

Methods: A descriptive cross-sectional study was conducted among 322 fall-related injured persons in West and East emergency hospitals in Erbil City from September 2020 to February 2021. Study sample demography, location of injury, place of affected body regions, outcome, and hospital stay were analyzed.

Results: Of the 322 patients studied, $68.9 \%$ were males, and $31.1 \%$ were female. Less than half of the samples (48.8\%) were between the ages 18 to 36 years old. The most common location for fall-related injuries was residential facilities (44.1\%) followed by the place of work (35.1\%). According to the type of fall, fall from ground was $38.4 \%$, and fall from a fall height of $1-3$ meters was $48.8 \%$. Finally, according to the injury classification, more than half $(56.5 \%)$ of the study sample had a significant degree of severity. The discharged status of disposition at the emergency room had the highest percentage (64.9\%) of the study sample. There was a significant difference between the scores of the items of fall consequences and outcomes regarding to type of ground (soft or hard). There was a significant relationship between injury severity and fall height ( $p$-value $=0.00$ ).

Conclusion: Fall-related injuries are the most common cases at emergency departments in Erbil city. Among ages 18 to 36, men are more frequently exposed to falls than women. The highest risk of fall is occupation with construction laborers at the greatest risk. Fallrelated injury is a burden on the health care system, particularly on emergency services in developing countries like Iraq in relations cost of care and resources.

Key words: Fall, Unintentional fall, Injury severity, Fall height, Outcome.

Received: 17/03/2021

Accepted: 10/05/2021

Published: 30/05/2021

\section{INTRODUCTION}

Falls are a common cause of mortality in both sex and all age groups [1]. It is one of the common reasons for trauma care at emergency department (ED) visits among all age groups [2]. Fall-related injuries increase the cost on the health care system [3]. About half of falls result in injuries, and about $10 \%$ of those injuries are serious injuries such as head injuries and fractures or injuries to the joint [4]. Falls and resulting injuries are frequently need medical care [5].Globally, falls are a major public health problem. Each year about 646,000 fatal falls occur. It is the second leading cause of accidental injury death after road traffic injuries. In low- and middle-income countries, fatal falls occur over $80 \%$ [6]. It is one reason that leads to death and the 
Third. leading cause of non-fatal injuries [7]. Although fall-related injuries are usually reported in older age groups, other studies have shown that younger people (15-49 years) have been recognized as the most vulnerable group affected by fall-related injuries. In addition, men are twice as likely to as women to be affected by falls [8]. Two of the three significant causes of injury deaths - fall and road traffic injuries- are expected to increase in rank compared to other causes of death, with falls increasing to become the 17th leading cause of death. [9].In Kurdistan, Iraq, there is no current study about falls in all circumstances, including settings and injury-prone environments. The environmental, personal, and equipment risk factors for falls change in different communities. It is essential to know the severity of injuries and outcome of patients who sustain injuries by falls to be better prepared to manage these emergencies and to provide appropriate recommendations for prevention. This study will have a fundamental role in refining knowledge and will be recognized as a source of nurses and emergency staff. The finding of this study may help nurses and other healthcare professionals expand their knowledge and improve their practice related to fall-related injuries. This study aimed to explore the socio demographic characteristics, severity, interventions, and health outcomes associated with fallrelated injuries and determine the association between injury severity and fall height.

\section{METHODS}

A descriptive cross-sectional study of 322 fall-related injured persons in West and East emergency hospitals in Erbil City was conducted from September 2020 to February 2021 . The sample size was determined by $\mathrm{Z} 2 \mathrm{p} \mathrm{q} / \mathrm{d} 2, \mathrm{z}=$ confident interval $95 \%$ (1.96), $p=$ prevalence $=(0.30), q=(1-p)=$ (0.70), $d=$ sampling error (0.05) [10].
Patients who died upon injury or those who died in the emergency rooms (9) were omitted because there was no complete data regarding the circumstances of death and to avoid potential bias due to outcome measurement. The researcher obtained an approval letter from the Ethics Committee at Hawler Medical University/College of Nursing on September 2020 (number 833). The official approval was taken as well. The researcher prepared a questionnaire for collecting data based on the review literature. The questionnaire was reliable and accessible to the public. The questionnaire was checked by a panel of experts who have extensive experience from different specialties. Based on their comments, the questionnaire was corrected and modified for appropriate data collection. A pilot study was conducted on 30 fall-related injured persons selected purposively from East and West emergency hospitals in September 2020. The pilot study was beneficial to determine the reliability, clarity, acceptability and time estimation for each participant to give full data which was 2030 minutes. Reliability was determined using the Spearman-Brown formula. The following procedures were used in data analysis: descriptive statistical data analysis (frequency and percentage) and inferential statistical data analysis (independent sample t-test and Chi-square test). Data were analyzed using SPSS version 21 .

\section{RESULTS}

Table 1 shows the socio demographic characteristics of the sample. Nearly half of the sample $(48.8 \%)$ were aged 18 - 36 years old, and a majority were male was (68.9\%). $31.7 \%$ graduated from primary school, and $49.1 \%$ lived in urban areas. The majority of the sample $(86 \%)$ were Iraqi, more than a third (37.9\%) . 
identified their occupation as a worker, reported a social income status of and more than half (57.1\%) Sufficient daily needs.

Table 1: Distribution of socio demographic data of the study sample $(n=322)$

\begin{tabular}{|c|c|c|c|}
\hline The Characteristics & Subgroups & $F$. & $\%$ \\
\hline \multirow[t]{4}{*}{ Age groups } & $1-18$ Years & 91 & $(28.3)$ \\
\hline & $18-36$ Years & 157 & $(48.7)$ \\
\hline & $36-54$ Years & 44 & (13.7) \\
\hline & $>54$ Years & 30 & $(9.3)$ \\
\hline \multirow[t]{2}{*}{ Gender } & Male & 222 & (68.9) \\
\hline & Female & 100 & (31.1) \\
\hline \multirow[t]{7}{*}{ Education level } & Illiterate & 57 & $(17.7)$ \\
\hline & Able to read and write & 70 & (21.7) \\
\hline & Primary school & 85 & (26.4) \\
\hline & Secondary school & 33 & $(10.3)$ \\
\hline & College or institute & 22 & $(6.8)$ \\
\hline & Post graduate & 11 & (3.4) \\
\hline & Child (N. A.) & 44 & (13.7) \\
\hline \multirow[t]{3}{*}{ Residence } & Urban & 158 & $(49.1)$ \\
\hline & Rural & 95 & (29.5) \\
\hline & Suburban & 69 & (21.4) \\
\hline \multirow[t]{2}{*}{ Nationality } & Iraqi & 277 & (86) \\
\hline & Others & 45 & (14) \\
\hline \multirow[t]{7}{*}{ Occupation } & Manual employee & 9 & $(2.8)$ \\
\hline & Office (Government) employee & 14 & $(4.3)$ \\
\hline & Unemployed (house wife) & 75 & (23.3) \\
\hline & Retired & 10 & $(3.1)$ \\
\hline & Worker & 122 & (37.9) \\
\hline & Student & 48 & (14.9) \\
\hline & Child (N. A.) & 44 & (13.7) \\
\hline \multirow[t]{3}{*}{ Income } & Exceeds daily needs & 3 & $(0.9)$ \\
\hline & Sufficient for daily needs & 184 & $(57.1)$ \\
\hline & Insufficient for daily needs & 135 & (42) \\
\hline
\end{tabular}


Table 2 shows information regarding fallrelated injuries. The primary mode of arrival was by none-ambulance mode (87\%). Nearly half of the samples (44.1\%) were injured at a residential facility, followed by the workplace (35.1\%). Almost all falls (92.5\%) were unintentional, and $89.1 \%$ of falls were falls to a hard ground.
The most common mechanism of fall was fall from ground $38.4 \%$, and the most common fall height was fall from 1-3 meters (48.8\%). On the pain scale, $54.3 \%$ of the sample reported, and on the Glasgow Coma Scale, 91.3\% reported no head injury, and $79.2 \%$ received radiological investigation.

Table 2: Distribution of information regarding fall of the study sample $(n=322)$

\begin{tabular}{|c|c|c|c|}
\hline The characteristics & Subgroups & F. & $\%$ \\
\hline \multirow[t]{2}{*}{ Mode of Arrival } & Ambulance & 41 & $(12.7)$ \\
\hline & None-ambulance mode & 281 & (87.3) \\
\hline \multirow[t]{4}{*}{ Location of fall Occurrence } & Residential facility & 142 & $(44.1)$ \\
\hline & Sports facility & 26 & (8.1) \\
\hline & Work place & 113 & (35.1) \\
\hline & Public / Commercial area & 41 & (12.7) \\
\hline \multirow[t]{2}{*}{ Intentionality of fall } & Unintentional & 298 & $(92.5)$ \\
\hline & Intentional & 24 & $(7.5)$ \\
\hline \multirow[t]{2}{*}{ Ground of fall } & Soft & 35 & (10.9) \\
\hline & Hard & 287 & $(89.1)$ \\
\hline \multirow[t]{4}{*}{ Fall Height } & $<1$ Meter & 109 & (33.8) \\
\hline & $1-3$ Meters & 157 & $(48.8)$ \\
\hline & $3-6$ Meters & 51 & (15.8) \\
\hline & $>6$ Meters & 5 & $(1.6)$ \\
\hline \multirow[t]{2}{*}{ Level of Consciousness } & Conscious & 299 & (92.9) \\
\hline & Unconscious and or altered mental status & 23 & (7.1) \\
\hline \multirow[t]{4}{*}{ Pain Scale } & Mild pain & 7 & $(2.2)$ \\
\hline & Moderate pain & 132 & $(41)$ \\
\hline & Severe pain & 175 & $(54.3)$ \\
\hline & Unconscious & 8 & $(2.5)$ \\
\hline Total of Glasgow Coma Scale & No head injury GCS 15/15 & 294 & $(91.3)$ \\
\hline \multirow[t]{3}{*}{ (GCS) } & Severe head injury GCS 3-8 & 8 & $(2.5)$ \\
\hline & Moderate head injury GCS 9--12 & 18 & $(5.6)$ \\
\hline & Miner head injury GCS $13-15$ & 2 & $(0.6)$ \\
\hline \multirow[t]{3}{*}{ Radiology investigation } & No & 32 & (9.9) \\
\hline & X-Ray & 255 & $(79.2)$ \\
\hline & X-Ray with other radiology test & 35 & $(10.9)$ \\
\hline \multicolumn{2}{|l|}{ Mechanism of fall } & $\mathbf{F}$ & $\%$ \\
\hline \multicolumn{2}{|l|}{ Fall from ground } & 124 & $(38.4)$ \\
\hline \multicolumn{2}{|c|}{ Fall from stairs and scaffold } & 111 & $(34.5)$ \\
\hline \multicolumn{2}{|c|}{ Fall from building or structure } & 45 & $(14)$ \\
\hline \multicolumn{2}{|l|}{ Sport activity } & 27 & $(8.4)$ \\
\hline \multicolumn{2}{|l|}{ Others } & 15 & $(4.7)$ \\
\hline \multicolumn{2}{|l|}{ Total } & 322 & $(100)$ \\
\hline
\end{tabular}


Table 3 shows the characteristics of injuries. Of the sample, $53.1 \%$ has no soft tissue injury, $41.3 \%$ had no fracture, $99.1 \%$ had no spinal cord injury, and $97.3 \%$ had no visceral injury. More than half (56.5\%) of study sample had major degree of severity. Table 4 shows the frequencies and percentages of the treatment type and in terventions of the study sample, $27.3 \%$

Table 3: Distribution of the injury characteristics among study sample $(n=322)$

\begin{tabular}{|c|c|c|c|}
\hline The Characteristics & Subgroups & F. & $\%$ \\
\hline \multirow[t]{2}{*}{ Soft tissue injury } & None & 171 & $(53.1)$ \\
\hline & Yes & 151 & $(46.9)$ \\
\hline \multirow[t]{9}{*}{ Site of fracture } & None & 133 & $(41.3)$ \\
\hline & $\begin{array}{l}\text { Skull and } \\
\text { neck frac- } \\
\text { ture }\end{array}$ & 20 & $(6.2)$ \\
\hline & $\begin{array}{l}\text { Upper limb } \\
\text { fracture }\end{array}$ & 57 & $(17.7)$ \\
\hline & $\begin{array}{l}\text { Lower limb } \\
\text { fracture }\end{array}$ & 68 & $(21.1)$ \\
\hline & $\begin{array}{l}\text { Back frac- } \\
\text { ture }\end{array}$ & 11 & $(3.4)$ \\
\hline & $\begin{array}{l}\text { Chest frac- } \\
\text { ture }\end{array}$ & 5 & $(1.6)$ \\
\hline & $\begin{array}{l}\text { Pelvis frac- } \\
\text { ture }\end{array}$ & 15 & $(4.7)$ \\
\hline & Multiple & 13 & (4) \\
\hline & fracture & & \\
\hline Spinal cord injury & None & 319 & (99.1) \\
\hline $\mathrm{SCl}$ & Yes & 3 & $(0.9)$ \\
\hline \multirow[t]{2}{*}{ Visceral Injury } & No & 313 & (97.3) \\
\hline & Yes & 9 & $(2.7)$ \\
\hline Injury Severity & None & 0 & $(0.0)$ \\
\hline \multirow[t]{4}{*}{ Classification } & Minor & 104 & $(32.3)$ \\
\hline & Moderate & 29 & (9) \\
\hline & Major & 183 & $(56.8)$ \\
\hline & Death & 6 & (1.9) \\
\hline
\end{tabular}

was received back slab or cast for the affected area, $24.8 \%$ was received advice and giving medication, $22.4 \%$ was received open reduction and internal fixation, $15.6 \%$ was received wound dressing and suturing, $3.4 \%$ was received traction, others, craniotomy $2.8 \%$, surgical debridement and external fixation $2.5 \%$, laparotomy $1.2 \%$.

Table 4: Distribution of interventions of fall among the study sample $(n=322)$

\begin{tabular}{|c|c|c|c|}
\hline The Outcomes & $\begin{array}{l}\text { Sub- } \\
\text { groups }\end{array}$ & $F$. & $\%$ \\
\hline \multirow{3}{*}{$\begin{array}{l}\text { Open Reduction and } \\
\text { Internal Fixation }\end{array}$} & No & 250 & (77.6) \\
\hline & & & \\
\hline & Yes & 72 & $(22.4)$ \\
\hline \multirow[t]{2}{*}{ Laparotomy } & No & 318 & $(98.8)$ \\
\hline & Yes & 4 & $(1.2)$ \\
\hline Surgical debride- & No & 314 & (97.5) \\
\hline ment and external & & & \\
\hline fixation & Yes & 8 & $(2.5)$ \\
\hline \multirow[t]{2}{*}{ Craniotomy } & No & 313 & $(97.2)$ \\
\hline & Yes & 9 & $(2.8)$ \\
\hline \multirow{2}{*}{$\begin{array}{l}\text { Wound dressing and } \\
\text { suturing }\end{array}$} & No & 285 & $(88.5)$ \\
\hline & Yes & 50 & $(15.6)$ \\
\hline \multirow{2}{*}{$\begin{array}{l}\text { Back slab or cast for } \\
\text { affected area }\end{array}$} & No & 234 & (72.7) \\
\hline & Yes & 88 & $(27.3)$ \\
\hline \multirow[t]{2}{*}{ Traction } & No & 311 & $(96.6)$ \\
\hline & Yes & 11 & $(3.4)$ \\
\hline Advice and giving & No & 242 & $(75.2)$ \\
\hline \multirow[t]{2}{*}{ Medication } & & & \\
\hline & Yes & 80 & $(24.8)$ \\
\hline
\end{tabular}


Table 5 shows the differences between the fall consequences and outcomes regarding the ground of fall (soft or hard). There was a significant difference between the scores of the fall consequences and outcomes regarding ground of fall. A high significance was reported for open reduction and internal fixation $(p=0.00)$, advice and giving medication $(p=0.00)$, and disposition at emergency hospitals $(p=0.00)$ with back slab or cast for the affected area $(p=0.01)$, traction $(p=0.01)$ and significant association for open reduction and external fixation $(p=0.04)$. There was no significance at the $p \leq 0.05$ with craniotomy, laparotomy, wound dressing, and suturing. A significant relationship between injury severity and fall height was observed $(p=0.00)$.

Table 5: Distribution of the fall consequences and outcomes based on (Ground of fall) of the study sample $(n=322)$

\begin{tabular}{|c|c|c|c|}
\hline Fall outcomes & Ground of fall (f.) & Sig. $p$ value & $\begin{array}{l}\text { Sig. Level at } p . \\
\text { value } \leq 0.05\end{array}$ \\
\hline \multirow[t]{2}{*}{ 1- Open reduction and internal fixation } & Soft (35) & 0.000 & H.S. \\
\hline & Hard (287) & & \\
\hline \multirow[t]{2}{*}{ 2- Laparotomy } & Soft (35) & 0.156 & N.S. \\
\hline & Hard (287) & & \\
\hline 3- Surgical debridement and external & Soft (35) & 0.041 & S. \\
\hline fixation & Hard (287) & & \\
\hline \multirow[t]{2}{*}{ 4- Craniotomy } & Soft (35) & 0.963 & N.S. \\
\hline & Hard (287) & & \\
\hline \multirow[t]{2}{*}{ 5- Wound dressing and suturing } & Soft (35) & 0.289 & N.S. \\
\hline & Hard (287) & & \\
\hline \multirow[t]{2}{*}{ 6- Back slab or cast for affected area } & Soft (35) & 0.019 & S. \\
\hline & Hard (287) & & \\
\hline \multirow[t]{2}{*}{ 7- Traction } & Soft (35) & 0.015 & S. \\
\hline & Hard (287) & & \\
\hline \multirow[t]{2}{*}{ 8- Advice and giving medication } & Soft (35) & .0000 & H.S. \\
\hline & Hard (287) & & \\
\hline \multirow[t]{2}{*}{ 9- Disposition at emergency room } & Soft (35) & 0.000 & H.S. \\
\hline & Hard (287) & & \\
\hline
\end{tabular}


Table 6: Association between injury severity and fall height among the study sample $(n=322)$.

\begin{tabular}{|c|c|c|c|c|c|c|c|}
\hline \multirow{2}{*}{$\begin{array}{l}\text { Injury severity } \\
\text { classification }\end{array}$} & \multicolumn{4}{|c|}{ Fall height } & \multirow[t]{3}{*}{ Total } & \multirow[t]{4}{*}{$\chi^{2}$ value } & \multirow{4}{*}{$\begin{array}{l}\text { Sig. } \\
\text { value at } \\
\text { p. value } \\
0.05\end{array}$} \\
\hline & Less than & $>1-3 \mathrm{~m} F$ & $>3-6 \mathrm{~m}$ & $>6 \mathrm{~m} \mathrm{~F}$. & & & \\
\hline & one meter $f$. & $\%$ & F. & $\%$ & & & \\
\hline & $\%$ & & $\%$ & & & & \\
\hline \multirow[t]{2}{*}{ None } & 0 & 0 & 0 & 0 & 0 & & \\
\hline & 0.0 & 0.0 & 0.0 & 0.0 & 0.0 & & \\
\hline \multirow[t]{2}{*}{ Minor } & 57 & 38 & 9 & 0 & 0 & & \\
\hline & 17.7 & 11.8 & 2.8 & 0.0 & 0.0 & & \\
\hline \multirow[t]{2}{*}{ Moderate } & 18 & 11 & 0 & 0 & 0 & & \\
\hline & 5.6 & 3.4 & 0.0 & 0.0 & 0.0 & & \\
\hline \multirow[t]{2}{*}{ Major } & 82 & 60 & 38 & 0 & 3 & & \\
\hline & 25.5 & 18.6 & 11.8 & 0.0 & 0.9 & & \\
\hline \multirow[t]{2}{*}{ Death } & 0 & 0 & 0 & 4 & 2 & & \\
\hline & 0.0 & 0.0 & 0.0 & 1.2 & 0.6 & & \\
\hline \multirow[t]{2}{*}{ Total } & 157 & 109 & 47 & 4 & 5 & & \\
\hline & 48.8 & 33.8 & 14.6 & 1.2 & 1.6 & 74.213 & 0.000 \\
\hline
\end{tabular}

\section{DISCUSSIONS}

This study shows that majority of the sample as between 18 - 36 years old, which aligns with the Lohanathan et al. retrospective study in South India [11]. The sample had a larger proportion of males than females, which aligns with the Ahmad et al. study results of fatal falls [12]. Usually, men are exposed to falls more frequently than women because boys are more active at early ages than girls, and men are more physical workers than women. Based on the occupation, workers were more than a third of the study sample and aligns with Dong et al., Meena, and Punia, which reported that the highest risk of fall was occupation with construction laborers as the largest occupation at risk [13] [14]. The primary mode of arrival was by none-ambulance mode, consistent with earlier studies by Fayyaz et al. that demonstrated similar results [15]. Residential facility was the most common place of fall followed by the workplace as reported in the same study [16]. A higher proportion of falls were unintentional, and majority of fall ground was hard. Injuries from fall height of 1-3 meters were the highest which is similar to the results by iccer et al [17]. Falls from the ground were highest among the sample which agrees with the study done by Alfredsson [18]. The present study disagrees with the study by Grivna et al., which showed more patients had fallen from higher heights compared to ground level [19].Most of the sample population were conscious and had a Glasgow coma score of 15 . Most of the patients were stabilized and after primary care discharged directly from the emergency department, similar to study results 
done in South India done by Lohanathan et al [11]. X-Ray investigation was done for majority of the cases like the study by Dong et al [13]. Nearly half of sample population had soft tissue injuries similar to the retrospective study by Turgut et al. at the Emergency Department of Inonu University which reported the most common traumatic lesion of fall was soft tissue injury [1].Limbs were the commonly injured body part, similar to the study in India done by Kumar and Srivastava [20]. Nearly one percent of the study sample had spinal cord injuries, agreeing with the Oxley et al. study [21]. However, it disagrees with the Kennedy et al. study reporting nearly a quarter percent of falls had spinal cord injury which may be attributed to the long duration of the study and differences in the heights of fall [22]. More than half of the sample has a major degree of severity which disagreed with Luzia et al., which reported that most injuries were classified as mild. Fall-related injuries involved specific medical and nursing interventions such as sutures, dressings, casting, orthopedic and neurologic surgical procedures. The percentage of injuries resulting in death was $1.9 \%$ of cases similar to that reported by Luzia et al. [23]. In this study, nearly a quarter of the cases needed orthopedic surgery, which disagrees with the study by Alizo et al., which showed that more than half of the sample population needed orthopedic surgery [24]. Alizo et al. reported these findings among falls from height only and not all types of falls. The outcomes of patients falling on soft grounds compared to those falling on solid grounds were statistically significant, similar to a Turkish study done by icçer et al. [17]. The present study showed a significant relationship between injury severity and fall height, similar to a retrospective observational data-based study by Dickinson et al. which showed the same result [25].

\section{Conclusion}

Fall-related injuries are the most common cases at emergency departments in Erbil city. Men are exposed to falls more frequently than women among ages 18 to 36 years old. The highest risk of fall is occupation with laborers of construction at the highest risk. Fall-related injuries have serious implications on the burden of the health care system, particularly on emergency services in developing countries like Iraq in relation to cost of care and resources.

\section{Recommendation}

Falls at work can be prevented by safety instruction to different groups, and proper regulation and legislation. Environmental variation based on architectural design may prevent falls among susceptible risk groups.

\section{Conflict of interest}

The author reports no conflict of interests.

\section{References}

[1] Turgut K, Sarihan ME, Colak C, Güven T, Gür $A$, Gürbüz S. Falls from height: a retrospective analysis. World journal of emergency medicine. 2018;9(1):46.

[2] Murray et al. Disability-adjusted life years (DALYs) for 291 diseases and injuries in 21 regions, 1990-2010: a systematic analysis for the Global Burden of Disease Study 2010. The lancet. 2012 Dec 15;380(9859):2197223.

[3] Tuma et al. Epidemiology of workplacerelated fall from height and cost of trauma care in Qatar. International journal of critical illness and injury science. 2013 Jan;3(1):3. 
[4] Hill et al. fall rates in hospital rehabilitation units after individualized patient and staff education programmes: a pragmatic, stepped-wedge, cluster-randomised controlled trial. The Lancet. 2015 Jun 27;385 (9987):2592-9.

[5] Ersoye et al. Analysis and injury patterns of walnut tree falls in central Anatolia of turkey. World journal of emergency surgery. 2014 Dec; 9(1):1-5.

[6] Word Health Organization. Falls. Fact sheets. 2017. Available from https:// www.who.int/news-room/fact-sheets.

[7] Bunting J, Branche C, Trahan C, Goldenhar L. A national safety stand-down to reduce construction worker falls. Journal of safety research. 2017 Feb 1; 60:103-11.

[8] Shrestha R, Shrestha SK, Kayastha SR, Parajuli $N$, Dhoju D, Shrestha D. A comparative study on epidemiology, spectrum and outcome analysis of physical trauma cases presenting to emergency department of Dhulikhel Hospital, Kathmandu University Hospital and its outreach centers in rural area. Kathmandu University medical journal. 2013;11(3):241-6.

[9] World Health Organization. Injuries and violence: the facts 2014. Available from https://www.google.com/search? $\mathrm{q}=.+$ World+Health+Organization.+Injuries+ and+violence $3 A+$ the+facts+2014. \& rlz=1C1 CHBD_enIQ909IQ910\&oq $=.09$ World + Healt h+Organization.+Injuries+and+violence $\%$ $3 A+$ the+facts $+2014 .+$ \&aqs $=$ chrome. $.69 i 57$. 9943j0j15\&sourceid=chrome\&ie=UTF-8 .

[10] Araoye, M.O.Research methodology with statistics for health and social sciences. Ilorin: Nathadex Publisher. 2003. 115 (9), pp.25-120.

[11] Lohanathan A, Hazra D, Jyothirmayi CA, Kundavaram AP. An elucidation of pattern of injuries in patients with fall from height. Indian Journal of Critical Care Medicine: Peer-reviewed, Official Publication of Indian Society of Critical Care Medicine. 2020 Aug;24(8):683.

[12] Ahmad M, Rahman FN, Al-Azad MA, Majumder MR, Chowdhury MH. Pattern of fatal injury in fall from height cases-a medicolegal study. Journal of Armed Forces Medical College, Bangladesh. 2014;10 (1):80-4.

[13] Dong XS, Jackson R, Varda D, Betit E, Bunting J. Trends of fall injuries and prevention in the construction industry.
CPWR quarterly data report; 3rd quarter. July 2019.

[14] Meena PC, Punia RK. Socio-demographic profile of fatal cases of fall from height-SMS Hospital, Jaipur during the year 2015-16. Indian Journal of Forensic Medicine \& Toxicology. 2018 Apr; 2:93-8.

[15] Fayyaz et al. Pattern of fall injuries in Pakistan: the Pakistan national emergency department surveillance (Pak-NEDS) study. BMC emergency medicine. 2015 Dec;15(2):17.

[16] Haggag OG, Zamzam IS, Sharaf Eldin AA, Madboly AG, Morad MM. Pattern of fatal injuries of fall from height at great Cairo: a retrospective analytical study (2009-2013). The Egyptian Journal of Forensic Sciences and Applied Toxicology. 2016 Dec 1; 16 (2):97-116.

[17] İçer M, Güloğlu C, Orak M, Üstündağ M. Factors Affecting Mortality In Falls From Height. Turkish Journal of Trauma and Emergency Surgery. 2013 Nov 1;19(6):529-35.

[18] Alfredsson M. Fall injury patterns and injury severity at Colombo South Teaching Hospital, Sri Lanka. University of Gothenburg (doctoral dissertation). 2020.

[19] Grivna M, Eid HO, Abu-Zidan FM. Epidemiology, morbidity and mortality from fallrelated injuries in the United Arab Emirates. Scandinavian journal of trauma, resuscitation and emergency medicine. 2014 Dec;22 (1):1-7.

[20] Kumar JV, Srivastava AK. Pattern of injuries in fall from height. Journal of Indian Academy of Forensic Medicine. 2013;35(1):47-50.

[21] Oxley J, O’Hern S, Burtt D, Rossiter B. FallRelated Injuries While Walking in Victoria. Accident research Centre. 2016 Mar; 16(02). Accessed on line from http://www. victoriawalks. Org. au/Assets/Files/Fall-relatedinjuries-While-Walking. Report. pdf

[22] Kennedy P, Cox A, Mariani A. Spinal cord injuries as a consequence of falls: are there differential rehabilitation outcomes?. Spinal Cord. 2013 Mar;51(3):209-13.

[23] Luzia MD, Prates CG, Bombardelli CF, Adorna JB, Moura GM. Characteristics of falls with damage to hospitalized patients. Revista gaúcha de enfermagem. 2019;40(SPE).

[24] Alizo et al. Fall from heights: does height really matter?. European journal of trauma and emergency surgery. 2018 Jun; 44(3):411 -6 .

[25] Dickinson A, Roberts M, Kumar A, Weaver A, 
Lockey DJ. Falls from height: injury and mortality.

BMJ Military Health. 2012 Jun 1; 158(2):123-7. 